\title{
An investigation on the effects of supply chain management on improvement of firms' financial performance
}

\author{
Mohammad Mokhtari* and Abutorab Alirezaie
}

Department of Management and Accounting, South Tehran Branch, Islamic Azad University, Tehran, Iran

\section{CHRONICLE ABSTRACT}

Article history:

Received July 28, 2013

Received in revised format

20 November 2013

Accepted 4 January 2014

Available online

February 142014

Keywords:

Supply chain management

Trust

Financial performance

Saipa group

\begin{abstract}
Supply chain management plays essential role on improvement of the efficiency of production systems. It helps firms meet their expectations, deliver their products on time and build a good brand. This paper performs an empirical investigation to study the effect of good relationships among various suppliers on financial figures in an Iranian automaker. The proposed study investigates the effects of seven variables including communication, cooperation, commitment, compatibility, organization climate, dependency and trust on two financial figures including return on assets and return on equities. Using structural equation modeling, the study detects that communication, dependency and trust influence positively on return on assets. In addition, communication, cooperation, trust and commitment have positive impact on return on equities.
\end{abstract}

(C) 2014 Growing Science Ltd. All rights reserved.

\section{Introduction}

Supply chain management plays essential role on improvement of the efficiency of production systems (Huntley, 2006). It helps firms meet their expectations, deliver their products on time and build a good brand. During the past few years, many conceptual and empirical studies in operations management have embraced the idea that collaborative supplier-buyer relationships were a source of competitive advantage for manufacturing organizations. Several anecdotal evidences from the Japanese and U.S. automotive industries imply that inter-organizational identification of suppliers with their buyers, termed supplier-to-buyer identification plays essential role on the success of organizations. Corsten et al. (2011) investigated on a model and reported that supplier-to-buyer identification fosters superior operational performance by enhancing trust, supplier relation-specific investments, and information exchange. According to Crosby et al. (1990), Salespeople involved in the marketing of complex services normally act the role of "relationship manager". They performed an empirical investigation to examine the nature, consequences, and antecedents of relationship 
quality, as perceived by the customer. They reported that future sales opportunities depend on relationship quality such as trust and satisfaction, whereas the ability to convert those opportunities into sales hinges more on conventional source characteristics of similarly and expertise. Faisal (2010) presented a hierarchy-based model and the mutual relationships among the enablers of sustainability in a supply chain using interpretive structural modeling. They explained that there was a group of enablers having a high-driving power and low-dependence requiring maximum attention and of strategic importance while another group consists of those variables, which had high dependences, and they were the resultant actions.

Flynn et al. (2010) extended the developing body of literature on supply chain integration (SCI) in order to reach effective and efficient flows of products and services, information, money and decisions, to provide maximum value to the customer. They used hierarchical regression to determine the effect of individual SCI dimensions including customer, supplier and internal integration and their interactions on performance. They reported that internal and customer integration were more strongly associated with improving performance than supplier integration. Ford and Håkansson (2006) reinvestigated the challenges made in the original International Marketing and Purchasing (IMP) project, in the light of all the changes that have happened in the business world since 1982. They reported that the challenge to ideas on the structure of the business world was partially accepted.

There is a substantial body of scholarly work concentrating on the interaction among the various dimensions of supply chain (SC) relationships including trust, commitment, adaptation, communication and collaboration but far less on the effect of SC relationships on performance. There has also been a substantial body of empirical research investigating the impact of quality practices on quality performance. Fynes et al. (2005) considered whether it is possible to measure the multidimensional nature of SC relationships and measured the effect of SC relationships on quality performance. Harland (1996) investigated supply chain issues in various countries and reported that trust, friendliness and other features of longer-term co-operative relationships would not guarantee bigger understanding and bigger satisfaction but rather that we have to understand the gap between expectations and perceptions of performance in relationships to make improvements that count. Ryssel et al. (2000) provided some empirical evidence to develop framework based on an empirical study with 60 German firms engaged in customer-supplier relationships. They argued that with regard to relationship management intra- and inter-organizational information technology deployment had various impacts on relationship atmosphere (i.e. trust and commitment) and on the value creation in the relationship. Saad et al. (2002) investigated the early progress towards the adoption of supply chain management (SCM) relationships in construction. They reviewed and surveyed of the views of construction practitioners and contend that SCM had many of the features associated with a "fifth generation innovation'. They concluded that although construction practitioners had some knowledge of SCM we need a better conceptual understanding of it.

\section{The proposed study}

The proposed study investigates the effects of seven variables including communication, cooperation, commitment, compatibility, organization climate, dependency and trust on two financial figures including return on assets and return on equities. The study designed a questionnaire in Likert scale and distributed it among some expert who worked for Saipa Group, an Iranian automaker. The sample size is calculated as follows,

$n=\frac{N \times z_{\alpha / 2}^{2} \times p \times q}{\varepsilon^{2} \times(N-1)+z_{\alpha / 2}^{2} \times p \times q}$,

where $N$ is the population size, $p=1-q$ represents the yes/no categories, $z_{\alpha / 2}$ is CDF of normal distribution and finally $\varepsilon$ is the error term. Since we have $p=0.5, z_{\alpha / 2}=1.96$ and $N=800$, the number of sample size is calculated as $n=65$. In order to validate the questionnaire, we have selected a group 
of 6 people and asked them to verify the overall questionnaire. Cronbach alpha have been calculated for communication, cooperation, commitment, compatibility, dependency, trust, organizational climate are $0.96,0.95,0.95,0.91,0.94,0.93$ and 0.94 , respectively. In addition, Cronbach alpha for return on assets and return on equities are 0.93 and 0.90 , respectively. Table 1 demonstrates the summary of factor loading, Cronbach alpha and other factors.

Table 1

The summary of findings

\begin{tabular}{|c|c|c|c|c|c|c|c|c|c|}
\hline Variable & Factor loading & $\begin{array}{c}\text { Cronbach } \\
\alpha\end{array}$ & Mean & $\begin{array}{l}\text { Combined } \\
\text { factor }\end{array}$ & Variable & $\begin{array}{c}\text { Factor } \\
\text { loading }\end{array}$ & $\begin{array}{c}\text { Cronbach } \\
\alpha\end{array}$ & Mean & $\begin{array}{l}\text { Combined } \\
\text { factor }\end{array}$ \\
\hline Comml & 0.97 & & & & Trust 1 & 0.83 & & & \\
\hline Comm2 & 0.97 & & & & Trust2 & 0.91 & 0.9 & 0.93 & 0.77 \\
\hline Comm3 & 0.93 & 0.94 & 0.96 & 0.85 & Trust3 & 0.89 & & & \\
\hline Comm4 & 0.8 & & & & Trust4 & 0.89 & & & \\
\hline Coll1 & 0.9 & & & & ROE1 & 0.81 & & & \\
\hline Coll2 & 0.9 & & & & ROE2 & 0.92 & 0.91 & 0.93 & 0.78 \\
\hline Coll3 & 0.95 & 0.93 & 0.95 & 0.81 & ROE3 & 0.95 & & & \\
\hline Coll4 & 0.86 & & & & ROE4 & 0.85 & & & \\
\hline Comit1 & 0.91 & & & & Climate1 & 0.89 & & & \\
\hline Comit2 & 0.96 & 0.92 & 0.95 & 0.86 & Climate2 & 0.95 & 0.89 & 0.94 & 0.845 \\
\hline Comit3 & 0.9 & & & & Climate3 & 0.92 & & & \\
\hline ROA1 & 0.8 & & & & Depen1 & 0.85 & & & \\
\hline ROA2 & 0.86 & 0.86 & 0.90 & 0.7 & Depen2 & 0.91 & 0.91 & 0.94 & 0.8 \\
\hline ROA3 & 0.87 & & & & Depen3 & 0.89 & & & \\
\hline ROA4 & 0.82 & & & & Depen4 & 0.93 & & & \\
\hline Con 1 & 0.95 & & & & & & & & \\
\hline Con2 & 0.84 & 0.86 & 0.91 & 0.78 & & & & & \\
\hline Con 3 & 0.86 & & & & & & & & \\
\hline
\end{tabular}

The proposed study of this paper uses structural equation modeling to study the effects of various factors on two major financial figures, namely; return on assets and return on equities. Next, we present details of our findings on testing these factors.

\section{The results}

In this section, we present details of our findings on examining the effects different factors on return on assets as well as return on equities. Fig. 1 demonstrates the results of our survey.

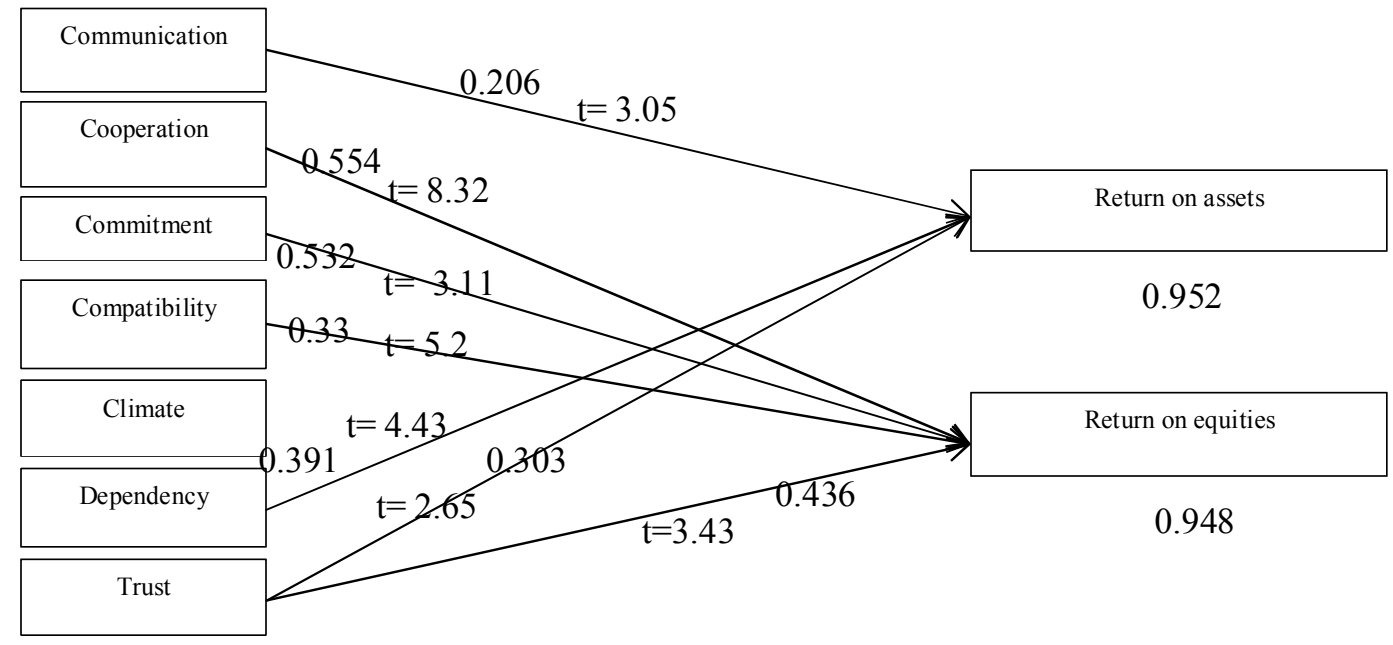

Fig. 1. The result of the implementation of structural equation modeling 
As we can observe from the results of Fig. 1, communication, dependency and trust influence on return on assets. In addition, cooperation, commitment, compatibility and trust influence positively on return on equities. While, trust has the highest impact on return on assets, cooperation maintains the highest impact on return on equities.

\section{Conclusion}

In this paper, we have presented an empirical investigation to study the effects of different factors of supply chain management on return on assets as well as return on equities. The study has disclosed that among various factors trust and cooperation will influence return on assets and return on equities, significantly. In other words, the study has detected that there was a positive and meaningful relationships between communication, dependency and trust on one side and return on assets on the other side. In addition, communication, cooperation, trusts and commitment influenced on return on equities, positively.

\section{Acknowledgement}

The authors would like to appreciate the help provided by anonymous referees to improve the quality of this paper.

\section{References}

Corsten, D., Gruen, T., \& Peyinghaus, M. (2011). The effects of supplier-to-buyer identification on operational performance-An empirical investigation of inter-organizational identification in automotive relationships. Journal of Operations Management, 29(6), 549-560.

Crosby, L. A., Evans, K. A., \& Cowles, D. (1990). Relationship quality in services selling: An interpersonal influence perspective. Journal of marketing, 54(3), 68-81.

Faisal, M. N. (2010). Sustainable supply chains: a study of interaction among the enablers. Business Process Management Journal, 16(3), 508-529.

Flynn, B. B., Huo, B., \& Zhao, X. (2010). The impact of supply chain integration on performance: a contingency and configuration approach. Journal of Operations Management, 28(1), 58-71.

Ford, D., \& Håkansson, H. (2006). IMP-some things achieved: much more to do. European Journal of Marketing, 40(3/4), 248-258.

Fynes, B., Voss, C., \& de Búrca, S. (2005). The impact of supply chain relationship quality on quality performance. International Journal of Production Economics, 96(3), 339-354.

Harland, C. (1996). International comparisons of supply-chain relationships. Logistics Information Management, 9(4), 35-38.

Huntley, J. K. (2006). Conceptualization and measurement of relationship quality: linking relationship quality to actual sales and recommendation intention. Industrial Marketing Management, 35(6), 703-714.

Ryssel, R., Ritter, T., \& Gemünden, H. G. (2000). Trust, commitment and value-creation in interorganizational customer-supplier relationships. In Proceedings of the Sixteenth IMP-Conference, Bath, UK.

Saad, M., Jones, M., \& James, P. (2002). A review of the progress towards the adoption of supply chain management (SCM) relationships in construction. European Journal of Purchasing \& Supply Management, 8(3), 173-183. 